\title{
Инновационное развитие сферы туризма степных регионов России
}

\author{
В.П. Чибилёва, И.Ю. Филимонова ${ }^{\varpi}$, Н. Ю. Святоха \\ Институт степи Уральского отделения Российской академии наук - \\ обособленное структурное подразделение \\ Федерального государственного бюджетного учреждения науки \\ Оренбургский федеральный исследовательский центр \\ Уральского отделения Российской академии наук, Российская Федераџия \\ (460000, г. Оренбург, ул. Пионерская, 11)
}

\begin{abstract}
Аннотация: Цель - дать оценку инновационному развитию туристской сферы степных регионов России с учетом современных вызовов.

Maтериаль и методы. Информационной базой служили статистические данные Федеральной службы государственной статистики, Федерального агентства по туризму, Министерства экономического развития, материалы научных электронных библиотек (eLIBRARY.RU, DisserCat). На основе авторской методики для комплексной оценки инновационного развития туристской сферы степных регионов России отобраны оптимизированные показатели, отражающие инновационное развитие исследуемых территорий (число туроператоров - разработчиков нового турпродукта; число мероприятий, направленных на презентацию туристских ресурсов; число особых экономических зон туристско-рекреационного типа и количество туристских кластеров; количество научных публикаций о туризме и др.). В результате анализа, унификации и суммирования обозначенных показателей была составлена картосхема, наглядно отражающая инновационное развитие сферы туризма степных регионов России. Всесторонне оценить инновационное развитие туристской сферы степных регионов позволили сравнительно-географический, статистический и геоинформационный методы исследования.

Результаты и обсуждение. В целом инновационное развитие сферы туризма степных регионов России можно оценить как равномерное, разбег значений между большинством регионов невелик. Тем не менее, отчетливо выделяются регионы-лидеры (Крым, Севастополь, Белгородская область) и аутсайдеры (Волгоградская, Саратовская области, ряд республик Северного Кавказа).

Bыводы. Для развития туристской сферы и внедрения инноваций, прежде всего, необходимо: создание новых особых экономических туристско-рекреационных кластеров и зон, число которых в степных регионах незначительно; создание системы научного и кадрового сопровождения туристской сферы в регионе; совершенствование системы налогообложения организаций, причастных к инновациям в сфере туризма.
\end{abstract}

Ключевые слова: инновационное развитие, сфера туризма, степные регионы.

Источник финансирования: Статья подготовлена в рамках темы государственного задания «Проблемы степного природопользования в условиях современных вызовов: оптимизация взаимодействия природных и социально-экономических систем». Номер государственной регистрации АAАA-A21-121011190016-1.

Для цитирования: Чибилёва В.П., Филимонова И. Ю., Святоха Н.Ю. Инновационное развитие сферы туризма степных регионов России // Вестник Воронежского государственного университета. Серия География. Геоэкология, 2021, № 4, c. 3-12. DOI: https://doi.org/10.17308/geo.2021.4/3744

\section{ВВЕДЕНИЕ}

Туристская сфера представляет собой динамичный и быстро растущий сектор экономики, внося весомый вклад в формирование валового внутрен- него продукта, способствуя созданию рабочих мест, развитию инфраструктуры, росту предпринимательской и инвестиционной активности, повышению уровня жизни местного населения, расширению межрегионального сотрудничества.

( С Чибилёва В.П., Филимонова И. Ю., Святоха Н. Ю., 2021

$\bowtie$ Филимонова Ирина Юрьевна, e-mail: filimo-irina@yandex.ru Контент доступен под лицензией Creative Commons Attribution 4.0 License. 
Наличие в степных регионах России уникальных туристских ресурсов, а также возрастающий интерес к внутреннему туризму в связи со снижением международной и межрегиональной мобильности, позволяет рассматривать туристскую сферу в качестве одной из важных отраслей экономики, для которой необходима оценка инновационного развития.

Инновации в туристской сфере способствуют привлечению новых идей, услуг и продуктов на рынок, что позволяет сфере туризма переходить на более высокий уровень развития. От внедрения инноваций зависит конкурентоспособность туристской сферы. Помимо экономического эффекта внедрение инноваций в сферу туризма имеет также и социальную значимость. Сфера туризма, по мнению ряда ученых (например, [8]), является одной из самых инновационных, включающей технологические и социальные достижения.

В различных источниках представлены разнообразные трактовки понятия «инновация». В российском законодательстве ${ }^{1}$ инновации трактуются как введенный в употребление новый или значительно улучшенный продукт (товар, услуга) или процесс, новый метод продаж или новый организационный метод в деловой практике, организации рабочих мест или во внешних связях.

Инновации, согласно А-М. Хьялагер [8], могут относиться к одной или к комбинации следующих пяти категорий: 1) продуктовые инновации (полностью новые продукты или услуги, новизна которых очевидна - программы лояльности и привлечения клиентов, экологичные объекты размещения, а также фестивали местной культуры); 2) процессные инновации (новые технологии, повышающие эффективность всего технологического процесса - компьютеризированные системы управления и мониторинга туристской сферы, роботы для уборки и обслуживания, а также устройства самообслуживания); 3) управленческие инновачии (новые профили и должности персонала, внедрение системы повышения квалификации и т.д.); 4) логистические инновации (например, модернизация связей между организациями туристской сферы и предприятиями питания, усовершенствование транспортных узловых систем); 5) институциональные инновации (например, изменение условий получения финансирования учреждениями, причастными к сфере туризма, изменение концепций отдельных видов туризма на государственном уровне).

В зарубежной литературе можно особо выделить ряд публикаций, посвященных систематизации информации на тему «инновации в туризме». К таким работам следует отнести статью В. Пиккемаат [9], в которой выделяются четыре основных направления исследований инноваций в сфере туризма: изучение процессных инноваций (с акцентом на то, что туризм становится отраслью, которая гораздо интенсивнее сотрудничает с другими отраслями, это позволяет создавать межотраслевые и кросс-функциональные команды); изучение конфигураций организаций или их сетей; изучение влияния науки и технологий (на основе анализа ряда источников автором сделан вывод о том, что накопление и передача знаний в туризме, особенно в сфере туристских услуг, зависят от сотрудников, их восприятия и поведения на рабочем месте, они также зависят и от клиентов, которые принимают участие в создании туристских услуг и продуктов); изучение эко-инноваций (в контексте туризма эти исследования находятся в зачаточном состоянии).

Большинство отечественных научных работ посвящено оценке сферы туризма в региональном разрезе $[2,3,6,7]$. Несмотря на увеличивающийся объем научных работ, посвященных инновациям в сфере туризма [5], лишь небольшое количество исследований посвящено изучению инновационного развития туристской сферы отдельных регионов России.

Степная зона богата природными и историко-культурными объектами, привлекательными для туристов. Разнообразие, контрастность, уникальность туристских ресурсов степных регионов связаны с особенностями освоения, историко-культурного развития территории, её природными, физико-географическими (нахождение в сердце единого Евразийского пространства: в двух частях света, и различных природных странах), социально-экономическими особенностями [1], что является основой развития различных направлений туризма. В связи с вышесказанным, цель данного исследования - дать оценку инновационного развития туристской сферы степных регионов России с учетом современных вызовов.

\footnotetext{
${ }^{1}$ Федеральный закон «О внесении изменений в Федеральный закон "О науке и государственной научно-технической политике"»: федер. закон от 21.07.2011 № 254-Ф3. URL: http://www.consultant.ru/document/cons_doc_LAW_358795/ (дата обращения: 13.03.21)
} 


\section{МАТЕРИАЛЫ И МЕТОДЫ}

Инновации в туристской сфере способствуют ее приспособлению к изменяющемуся характеру туризма посредством новых технологий, появления новаторских продуктов, услуг и процессов.

Авторами, с учетом имеющихся статистических данных, были выбраны оптимизированные показатели, наиболее полно отражающие инновационное развитие исследуемого региона.

Основными инновационными индикаторами, позволяющими охарактеризовать инновационное развитие степных регионов, нами принято 12 унифицированных показателей, расчетные величины которых отражены в таблице.

$1^{\text {a }}$. Итоговый рейтинг инновационного развития субъектов Российской Федерации, рассчитанный НИУ ВШЭ [4] [The final rating of innovative development of the constituent entities of the Russian Federation, calculated by the Higher School of Economics].

$2^{\text {b }}$. Уровень инновационной активности организаций по субъектам Российской Федерации ${ }^{2}$ [The level of innovation activity of organizations in the constituent entities of the Russian Federation] (Показатель рассчитан в соответствии с международными рекомендациями по статистическому измерению инноваций, реализуемому ОЭСР совместно с Евростатом).

$3^{c}$. Объем инновационных товаров на 1000 жителей (млн. руб. на 1000 чел.) ${ }^{2}$ [The volume of innovative products (million rubles per 1000 people)].

4 d. Объем инвестиций в коллективные средства размещения (в пересчете на число коллективных средств размещения) ${ }^{3}$ [The volume of investments in collective placement facilities (in terms of the number of collective placement facilities)].

5 e. Численность работающих в турфирмах (в пересчете на численность населения регионов $)^{3}$ [The number of employees of tourist companies (in terms of the population of the regions)]. 6f. Число туроператоров (в пересчете на численность населения регионов) ${ }^{3}$ [Number of tour operators (based on the population of the regions)].

$7^{\text {g. }}$ Численность студентов, обучающихся по направлению «Туризм» (в пересчете на численность населения регионов) ${ }^{3}$ [The number of students in the direction of training "Tourism" (in terms of the population of the regions)].

$8^{\mathrm{h}}$. Число туристских информационных центров (в пересчете на численность населения регионов) [Number of tourist information centers (based on the population of the regions)], ведущих рекламную деятельность, позволяющую определить приоритеты в выборе места отдыха потенциальному туристу ${ }^{3}$.

9і. Число официально зарегистрированных проведенных мероприятий (акций, конкурсов, фестивалей, выставочно-ярмарочных мероприятий и других), направленных на презентацию туристских ресурсов (в пересчете на численность населения регионов) ${ }^{4}$ [The number of officially registered events aimed at the presentation of tourist resources (in terms of the population of the regions)].

10.. Число защит диссертаций (кандидатских и докторских) по туристской тематике (в пересчете на численность населения регионов) ${ }^{5}$ [The number of defenses of candidate and doctoral theses on tourism topics in the regions of the steppe zone (in terms of the population of the regions)].

$11^{\mathrm{k}}$. Количество особых экономических зон туристско-рекреационного типа ${ }^{6}$ и количество туристских кластеров в степных регионах (в пересчете на численность населения регионов $)^{7}$ [Number of special economic zones of tourist and recreational type and tourist clusters (in terms of the population of the regions)].

$12^{1}$. Количество научных публикаций о туризме в регионе на сайте научно-электронной библиотеки Elibrary.ru (в пересчете на численность на-

\footnotetext{
${ }^{2}$ Единая межведомственная информационно-статистическая система. Официальный сайт федеральной службы государственной статистики. URL: https://rosstat.gov.ru/emiss (дата обращения: 14.03.21)

${ }^{3}$ Статистические данные по РФ. Официальный сайт Федерального агентства по туризму. URL: https://tourism.gov.ru/ contents/statistika/ (дата обращения: 14.02.21)

${ }^{4}$ Единая межведомственная информационно-статистическая система. Официальный сайт федеральной службы государственной статистики. URL: https://rosstat.gov.ru/emiss. (дата обращения: 14.02.21)

${ }_{5}^{5}$ DisserCat - научная электронная библиотека диссертаций и авторефератов. URL: https://www.dissercat.com/ (дата обращения: 11.03.21)

${ }^{6}$ ОЭЗ туристско-рекреационного типа. Официальный сайт Министерства экономического развития Российской Федерации. URL: https://www.economy.gov.ru/material/directions/regionalnoe_razvitie/instrumenty_razvitiya_territoriy/osobye_ ekonomicheskie_zony/oez_turistsko_rekreacionnogo_tipa/ (дата обращения: 14.02.21)

7 Подпрограмма «Туризм» государственной программы Российской Федерации «Развитие культуры и туризма». Официальный сайт Федерального агентства по туризму. URL: https://tourism.gov.ru/contents/deyatelnost/programmy-i-proekty/ gosudarstvennye-programmy-realizovannye-rosturizmom-do-2020-goda/gosudarstvennaya-programma-rossiyskoy-federatsiirazvitie-kultury-i-turizma-na-2013-2020-gody/ (дата обращения: 14.02.21)
}

Вестник ВГУ, Серия: География. Геоэкология, 2021, № 4, 3-12 
селения регионов $)^{8}$ [The number of scientific publications on tourism topics (in terms of the population of the regions)].

Помимо обозначенных показателей целесообразно дополнительно рассматривать количество исследовательских проектов и патентов в сфере туризма; количество совместных проектов в рамках сотрудничества университетов, научно-исследовательских институтов и организаций, связанных с туристской деятельностью; объем средств, привлеченных в рамках грантовой и хоздоговорной деятельности для исследования туристской сферы регионов; количество товарных знаков, зарегистрированных брендов, связанных с туризмом; количество проектов в рамках научно-исследовательских и опытно-конструкторских работ, связанных с внутренним туризмом в степных регионах; масштабы государственно-частного партнерства в сфере туризма; финансовые вложения в туристскую сферу регионов; объем средств в рамках программ развития туризма (нередко он неотделим от спортивной составляющей); наличие инновационной инфраструктуры в регионе (технологические парки, бизнес-инкубаторы в туристской сфере, технополисы, научно-образовательные центры и другое); наличие инновационно-информационных систем в туристской сфере; число информационных и рекламных материалов, содержащих сведения о туристском потенциале регионов. К сожалению, по данным показателям полноценная статистика во всех степных регионах не ведется, что затрудняет использование этих данных для расчета интегрального показателя.

Комплексная оценка инновационного развития сферы туризма степных регионов России проведена по указанным выше индикаторам. Все индикаторы приведены к унифицированной шкале следующим образом:

$$
x_{i}^{*}=\frac{x_{i}-x_{\min }}{x_{\max }-x_{\min }} \times N,
$$

где $x_{i},-$ значение переменной і-ого наблюдения, $x_{\min }$ и $x_{\max }-$ соответственно наименьшее и наибольшее наблюдаемые значения переменной, $\mathrm{N}=1$.

Далее было проведено суммирование показателей, итоговый рейтинг представлен в виде картосхемы.
Говоря о методах исследования, отметим, что сравнительно-географический в совокупности со статистическим и геоинформационным методами позволили всесторонне оценить инновационное развитие туристской сферы степных регионов.

По итогам полевых исследований, с учётом ряда факторов, были составлены рекомендации, которые могут быть использованы органами власти при проведении региональной политики в сфере туризма.

\section{ОБСУЖДЕНИЕ РЕЗУЛЬТАТОВ}

На основе авторской методики дана оценка инновационного развития туристской сферы степных регионов России. Рассмотрим обозначенные нами индикаторы на территории степных регионов.

Динамика показателя инвестиций в основной капитал, направленных на развитие коллективных средств размещения в степных регионах, не имеет четко выраженных годовых трендов, тем не менее, пространственные различия между регионами по данному показателю остаются практически неизменными, что позволяет ограничиться значениями за один год при расчете интегрального показателя. Из года в год абсолютные лидеры по объемам инвестиций такие субъекты страны, как Республика Крым, Краснодарский край, Севастополь и Республика Башкортостан.

Число туроператоров, занимающихся разработкой нового турпродукта и апробацией новых туристских маршрутов, существенно возросло с 2010 года во всех регионах. В 2021 году максимальное число туроператорских фирм приходится на Краснодарский край, минимум - на Ингушетию и Калмыкию. По состоянию на 2010 год максимальное количество туроператоров составляло всего 2 единицы (по два туроператора было зарегистрировано в Саратовской, Ростовской и Белгородской областях). А в 2021 году суммарное количество туроператоров в степной зоне составило 679 единиц 9.

Численность работников турфирм максимальна в Краснодарском крае и Новосибирской области. Общая тенденция в степной зоне России - сокращение численности официально трудоустроенных в турфирмах лиц (за исключением республик Северного Кавказа) ${ }^{9}$.

Абсолютная численность студентов по направлению подготовки «Туризм» максимальна в Крас-

\footnotetext{
${ }^{8}$ eLIBRARY.RU - Научная электронная библиотека. URL: https://elibrary.ru/defaultx.asp?. (дата обращения: 11.03.21)

${ }_{9}^{9}$ Статистические данные по РФ. Официальный сайт Федерального агентства по туризму. URL: https://tourism.gov.ru/ contents/statistika/ (дата обращения: 11.03.21)
} 
нодарском крае и Ростовской области. В пересчете на численность населения регионов максимальные показатели - в Омской и Воронежской областях.

Туристские информационные центры в степных регионах России пока не имеют единой сформированной сети. Они работают лишь в отдельных регионах. Лидер по количеству расположенных в регионе туристских информационных центров - Республика Крым, где зарегистрирован 21 центр, что коррелирует с общими показателями потока туристов в регион. Во всех остальных регионах их количество не превышает 4 , а в Республике Адыгея, Саратовской области и городе Севастополе они отсутствуют. Туристские информационные центры функционируют там, где они получают финансирование. Центры способствуют росту туристской популярности и привлекательности территории.
Число официально зарегистрированных проведенных мероприятий, направленных на презентацию туристских ресурсов, максимально в Воронежской и Курганской областях, практически отсутствуют - в Северной Осетии и Ставропольском крае.

В ряде степных регионов отсутствуют как особые экономические зоны туристско-рекреационного типа, так и туристские кластеры.

Число защит кандидатских и докторских диссертаций по оценке туристской сферы в регионах степной зоны, а также количество научных публикаций на туристско-рекреационную тематику максимально в республике Крым и Краснодарском крае.

По всем показателям было проведено унифицирование по шкале от 0 до 1 , затем показатели суммировались для определения интегрального показателя. Результаты вычислений представлены в таблице.

Таблица

Интегральный показатель инновационного развития сферы туризма степных регионов

[Table. Integral indicator of innovative development of tourism in the steppe regions]

\begin{tabular}{|c|c|c|c|c|c|c|c|c|c|c|c|c|c|}
\hline \multirow{2}{*}{$\begin{array}{l}\text { Регион / } \\
\text { Region }\end{array}$} & \multicolumn{12}{|c|}{ Унифицированные показатели / Unified indicators } & \multirow{2}{*}{$\begin{array}{c}\text { Инте- } \\
\text { граль- } \\
\text { ный по- } \\
\text { казатель } \\
\text { / Integral } \\
\text { indicator }\end{array}$} \\
\hline & $1^{\mathrm{a}}$ & $2^{b}$ & $3^{c}$ & $4^{\mathrm{d}}$ & $5^{\mathrm{e}}$ & $6^{\mathrm{f}}$ & $7^{\mathrm{g}}$ & $8^{\mathrm{h}}$ & $9^{i}$ & $10^{\mathrm{j}}$ & $11^{\mathrm{k}}$ & $12^{1}$ & \\
\hline $\begin{array}{l}\text { Алтайский край / } \\
\text { Altai Krai }\end{array}$ & 0,35 & 0,73 & 0,06 & 0,21 & 0,25 & 0,39 & 0,46 & 0,04 & 0,10 & 0,00 & 0,11 & 0,27 & 2,96 \\
\hline $\begin{array}{l}\text { Белгородская } \\
\text { область / Belgorod } \\
\text { Oblast } \\
\end{array}$ & 0,41 & 0,86 & 1,00 & 0,04 & 0,20 & 0,32 & 0,73 & 0,06 & 0,10 & 0,20 & 0,00 & 0,26 & 4,17 \\
\hline $\begin{array}{l}\text { Волгоградская } \\
\text { область / Volgo- } \\
\text { grad Oblast }\end{array}$ & 0,31 & 0,27 & 0,12 & 0,01 & 0,26 & 0,27 & 0,00 & 0,04 & 0,21 & 0,12 & 0,00 & 0,13 & 1,74 \\
\hline $\begin{array}{l}\text { Воронежская } \\
\text { область / Voronezh } \\
\text { Oblast }\end{array}$ & 0,41 & 0,76 & 0,26 & 0,01 & 0,15 & 0,04 & 0,90 & 0,12 & 0,38 & 0,07 & 0,00 & 0,05 & 3,13 \\
\hline $\begin{array}{l}\text { г. Севастополь / } \\
\text { Sevastopol }\end{array}$ & 0,29 & 0,33 & 0,02 & 1,00 & 1,00 & 1,00 & 0,74 & 0,00 & 0,10 & 0,00 & 0,00 & 0,45 & 4,93 \\
\hline $\begin{array}{l}\text { Кабардино- } \\
\text { Балкарская } \\
\text { республика / } \\
\text { Kabardino-Balkar } \\
\text { Republic }\end{array}$ & 0,25 & 0,21 & 0,00 & 0,02 & 0,08 & 0,17 & 0,32 & 0,10 & 0,02 & 0,71 & 0,30 & 0,19 & 2,38 \\
\hline $\begin{array}{l}\text { Краснодарский } \\
\text { край / Krasnodar } \\
\text { Krai }\end{array}$ & 0,37 & 0,24 & 0,17 & 0,14 & 0,46 & 0,35 & 0,41 & 0,05 & 0,01 & 0,19 & 0,05 & 0,24 & 2,68 \\
\hline $\begin{array}{l}\text { Курганская область } \\
\text { / Kurgan Oblast } \\
\end{array}$ & 0,26 & 0,55 & 0,09 & 0,03 & 0,24 & 0,07 & 0,41 & 0,22 & 1,00 & 0,00 & 0,00 & 0,00 & 2,87 \\
\hline
\end{tabular}

Вестник ВГУ, Серия: География. Геоэкология, 2021, № 4, 3-12 
Продолжение таблицьь

\begin{tabular}{|c|c|c|c|c|c|c|c|c|c|c|c|c|c|}
\hline $\begin{array}{l}\text { Новосибирская } \\
\text { область / Novosi- } \\
\text { birsk Oblast }\end{array}$ & 0,44 & 0,44 & 0,09 & 0,10 & 0,56 & 0,23 & 0,82 & 0,07 & 0,02 & 0,00 & 0,00 & 0,02 & 2,78 \\
\hline $\begin{array}{l}\text { Омская область / } \\
\text { Omsk Oblast }\end{array}$ & 0,37 & 0,42 & 0,08 & 0,02 & 0,41 & 0,05 & 1,00 & 0,05 & 0,06 & 0,16 & 0,00 & 0,12 & 2,73 \\
\hline $\begin{array}{l}\text { Оренбургская } \\
\text { область / Orenburg } \\
\text { Oblast }\end{array}$ & 0,29 & 0,31 & 0,22 & 0,01 & 0,18 & 0,05 & 0,51 & 0,09 & 0,03 & 0,08 & 0,13 & 0,09 & 1,98 \\
\hline $\begin{array}{l}\text { Республика } \\
\text { Адыгея / Republic } \\
\text { of Adygea }\end{array}$ & 0,26 & 0,24 & 0,16 & 0,05 & 0,15 & 0,08 & 0,66 & 0,00 & 0,20 & 1,00 & 0,56 & 0,46 & 3,82 \\
\hline $\begin{array}{l}\text { Республика } \\
\text { Башкортостан / } \\
\text { Republic of Bash- } \\
\text { kortostan }\end{array}$ & 0,41 & 0,58 & 0,39 & 0,08 & 0,27 & 0,16 & 0,55 & 0,02 & 0,05 & 0,11 & 0,06 & 0,09 & 2,77 \\
\hline $\begin{array}{l}\text { Республика } \\
\text { Ингушетия / Re- } \\
\text { public of Ingushetia }\end{array}$ & 0,16 & 0,03 & 0,00 & 0,00 & 0,10 & 0,00 & 0,26 & 0,18 & 0,29 & 0,00 & 1,00 & 0,01 & 2,04 \\
\hline $\begin{array}{l}\text { Республика } \\
\text { Калмыкия / Re- } \\
\text { public of Kalmykia }\end{array}$ & 0,21 & 0,07 & 0,01 & 0,00 & 0,05 & 0,03 & 0,71 & 0,34 & 0,11 & 0,00 & 0,00 & 0,55 & 2,09 \\
\hline $\begin{array}{l}\text { Республика Крым / } \\
\text { Republic of Crimea }\end{array}$ & 0,26 & 0,25 & 0,00 & 0,72 & 0,38 & 0,50 & 0,43 & 1,00 & 0,17 & 0,56 & 0,13 & 1,00 & 5,41 \\
\hline $\begin{array}{l}\text { Республика } \\
\text { Северная Oсетия - } \\
\text { Алания / Republic } \\
\text { of North Ossetia - } \\
\text { Alania } \\
\end{array}$ & 0,24 & 0,08 & 0,00 & 0,00 & 0,08 & 0,07 & 0,70 & 0,13 & 0,00 & 0,00 & 0,37 & 0,10 & 1,77 \\
\hline $\begin{array}{l}\text { Ростовская область } \\
\text { / Rostov Oblast }\end{array}$ & 0,39 & 1,00 & 0,15 & 0,04 & 0,32 & 0,24 & 0,78 & 0,09 & 0,04 & 0,07 & 0,00 & 0,05 & 3,18 \\
\hline $\begin{array}{l}\text { Самарская область } \\
\text { / Samara Oblast } \\
\end{array}$ & 0,42 & 0,57 & 0,53 & 0,06 & 0,43 & 0,26 & 0,70 & 0,03 & 0,04 & 0,29 & 0,00 & 0,04 & 3,38 \\
\hline $\begin{array}{l}\text { Саратовская } \\
\text { область / Saratov } \\
\text { Oblast }\end{array}$ & 0,36 & 0,34 & 0,06 & 0,01 & 0,22 & 0,09 & 0,71 & 0,00 & 0,02 & 0,00 & 0,00 & 0,04 & 1,84 \\
\hline $\begin{array}{l}\text { Ставропольский } \\
\text { край / Stavropol } \\
\text { Krai }\end{array}$ & 0,33 & 0,28 & 0,16 & 0,00 & 0,28 & 0,19 & 0,57 & 0,03 & 0,00 & 0,11 & 0,00 & 0,09 & 2,04 \\
\hline $\begin{array}{l}\text { Челябинская } \\
\text { область / Chelya- } \\
\text { binsk Oblast] }\end{array}$ & 0,43 & 0,59 & 0,29 & 0,06 & 0,40 & 0,16 & 0,60 & 0,11 & 0,24 & 0,13 & 0,00 & 0,01 & 3,01 \\
\hline $\begin{array}{l}\text { Чеченская } \\
\text { Республика / } \\
\text { Chechen Republic }\end{array}$ & 0,22 & 0,00 & 0,00 & 0,00 & 0,00 & 0,00 & 0,51 & 0,06 & 0,13 & 0,31 & 0,17 & 0,09 & 1,50 \\
\hline
\end{tabular}

Интегральный показатель позволил выявить регионы-лидеры по уровню инновационного развития туристской сферы (рис.). К таким регионам в степной зоне России относятся - Республика Крым, город Севастополь и Белгородская область. Научный и инвестиционный интерес к Республике Крым возрос с 2010-х годов в связи с политическими событиями и значительным притоком туристов-россиян. Три указанных региона существенно выделяются среди других регионов степной зоны, интегральный показатель инновационного развития которых практически в два раза ниже (при том, что разбег значений между остальными регионами невелик). 


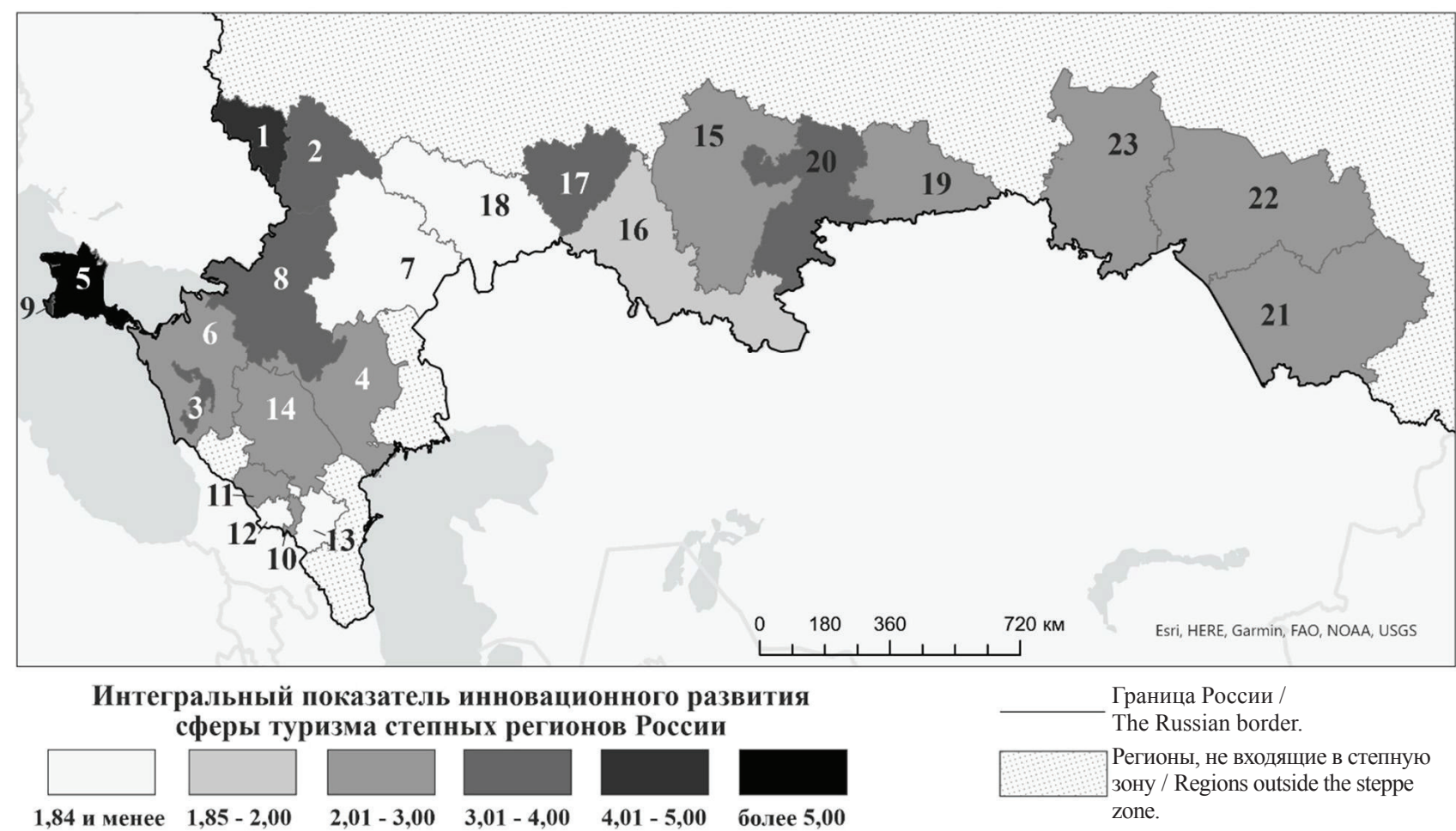

Цифрами на карте обозначены субъекты Российской Федерации, расположенные в степной зоне: 1 - Белгородская область, 2- Воронежская область, 3 - Республика Адыгея, 4 - Республика Калмыкия, 5 - Республика Крым, 6 - Краснодарский край, 7 - Волгоградская область, 8 - Ростовская область, 9 - г. Севастополь, 10 - Республика Ингушетия, 11 - Кабардино-Балкарская республика, 12 - Республика Северная Осетия - Алания, 13 - Чеченская Республика, 14 -Ставропольский край, 15 - Республика Башкортостан, 16 - Оренбургская область, 17 - Самарская область, 18 -Саратовская область, 19 - Курганская область, 20 - Челябинская область, 21 - Алтайский край, 22 - Новосибирская область , 23 - Омская область.

Puc. Интегральный показатель инновационного развития сферы туризма степных регионов России [Fig. Integral indicator of innovative development of tourism in the steppe regions of Russia]

Для развития сферы туризма авторами составлена дорожная карта «Инновационное развитие туристской сферы степных регионов» с учетом современных вызовов на основе нескольких сценариев в зависимости от региональной специфики.

Возможен кадровый сценарий, который предусматривает переподготовку специалистов, способных работать с туристами разных культур, носителями разных языков, в условиях кардинальной перестройки современного туристского производства, в частности, создание новых внутрифирменных стандартов обслуживания в сфере предоставления туристских и гостиничных услуг.

Инвестиционный сценарий связан с разработкой эффективной и грамотной стратегии развития, с помощью внедрения новых технологий и управленческих решений в сфере туризма. Инновационными направлениями для этого могут быть: 1) использование туристских ресурсов, не использовавшихся ранее в регионе; 2) регулярное воспроизводство туристского продукта (выпуск новых видов туристского продукта, гостиничных услуг, сферы питания и развлечений); 3) выявление ноВестник ВГУ, Серия: География. Геоэкология, 2021, № 4, 3-12 вых рынков сбыта туристского продукта; 4) применение современной техники и новых технологий в ходе реализации туристского продукта; 5) инновации в организации производства (участие органов власти, организаций науки и образования) и потреблении туристского продукта (диверсификация туристского продукта, индивидуализирование туристского продукта); 6) проведение научно-исследовательских работ, семинаров, обучение персонала; 7) организация выставок, ярмарок, фестивалей.

\section{ЗАКЛЮЧЕНИЕ}

Инновационное развитие сферы туризма степных регионов России в целом можно оценить как равномерное. Разбег значений между большинством регионов невелик. Тем не менее, отчетливо выделяются субъекты-лидеры (Крым, Севастополь, Белгородская область) и аутсайдеры (Волгоградская, Саратовская, Оренбургская области и ряд республик Северного Кавказа). Для развития туристской сферы и внедрения инноваций, прежде всего, необходимо: создание новых особых экономических туристско-рекреационных кла- 
стеров и зон, число которых в степных регионах незначительно, с соответствующим государственным финансированием; создание системы научного и кадрового сопровождения (от обучения до переподготовки) туристской сферы в регионе.

Целью инновационного развития туристской сферы ставится создание качественного туристского продукта; для этого необходимо готовить квалифицированные кадры, привлекать инвестиции, проводить совершенствование системы налогообложения организаций, причастных к инновациям в туристской сфере.

Обозначенные авторами рекомендации позволят применить на практике оптимизированную управленческую стратегию развития туристской сферы степных регионов России в условиях современных вызовов.

\section{СПИСОК ЛИТЕРАТУРЫ}

1. Грудинин Д. А., Чибилёв А. А. (мл.) Объекты природного наследия Оренбургско-Казахстанского приграничья и проблемы их освоения для целей рекреации и туризма // Бюллетень Оренбургского научного центра УрО РАН, электронный журнал, 2012, №4, с. 1-17.

2. Кайзер Ф.Ю. Туристский бренд территории как составляющая формирования туристского образа Кемеровской области (Кузбасса) // Вестник Воронежского государственного университета. Серия: География. Геоэкология, 2020, № 1, с. 67-76. DOI: https://doi. org/10.17308/geo.2020.1/2663.

3. Расковалов В.П. Природный туристский потенциал Пермского края // Вестник Воронежского государственного университета. Серия: Геогра- фия. Геоэкология, 2020, №2, с. 22-28. DOI: https://doi. org/10.17308/geo.2020.2/2881.

4. Рейтинг инновационного развития субъектов Российской Федерации, вып. 6 / Г.И. Абдрахманова, С. В. Артемов, П.Д. Бахтин и др.; под ред. Л. М. Гохберга; Нац. исслед. ун-т «Высшая школа экономики». Москва: НИУ ВШЭ, 2020. 264 с.

5. Швец Ю. Ю. Анализ факторов инновационного развития сферы туризма // Ученые записки Таврического нацчионального университета им. В.И. Вернадского. Серия «Экономика и управление», 2011, т. 24 (63), №1, с. 118-126.

6. Шеремет Е.Н. Роль экологического туризма в развитии муниципальных районов Новосибирской области // Вестник Воронежского государственного университета. Серия: География. Геоэкология, 2018, №4, с. 72-76. DOI: https://doi.org/10.17308/geo.2018.4/2270.

7. Яковлев И.Г. Туристско-рекреационное районирование степных регионов как основа выявления и обоснования ключевых элементов туристско-рекреационного каркаса // Проблемы региональной экологии, 2017, № 6, c. 83-87.

8. Hjalager A-M. 100 Innovations That Transformed Tourism//JournalofTravelResearch, 2015,v.54(1),pp.3-21. DOI: https://doi.org/10.1177\%2F0047287513516390.

9. Pikkemaat B., Peters M., Bichler B. F. Innovation research in tourism: Research streams and actions for the future // Journal of Hospitality and Tourism Management, 2019, v. 41, pp. 184-96. DOI: https://doi.org/10.1016/j.jhtm.2019.10.007.

Конфликт интересов: Авторы декларируют отсутствие явных и потенциальных конфликтов интересов, связанных с публикацией настоящей статьи.

Поступила в редакцию 11.05.2021

Принята к публикаџии 23.11.2021

UDC 911(338.78)

ISSN 1609-0683

DOI: https://doi.org/10.17308/geo.2021.4/3744

\title{
Innovative Development of Tourism in the Steppe Regions of Russia
}

\author{
V.P. Chibilyova, I.Yu. Filimonova ${ }^{\bowtie}$, N.Yu. Sviatokha \\ The Institute of the Steppe of the Ural Branch of the Russian Academy of Sciences- \\ a separate structural unit of the Federal State Budgetary Institution of Science \\ of the Orenburg Federal Research Center of the Ural Branch \\ of the Russian Academy of Sciences, Russian Federation \\ (11, Pionerskaya Str., Orenburg, 460000)
}

\begin{abstract}
The purpose of the study is to assess the innovative development of the tourism sector in the steppe regions of Russia, taking into account modern challenges.
\end{abstract}

(C) Chibilyova V.P. ,Filimonova I. Yu., Sviatokha N.Yu., 2021

$\triangle$ Irina Yu. Filimonova, e-mail: filimo-irina@yandex.ru

The content is available under Creative Commons Attribution 4.0 License. 
Methods. The information base was statistical data of the Federal State Statistics Service, the Federal Agency for Tourism, the Ministry of Economic Development, materials of scientific electronic libraries (eLIBRARY. RU, DisserCat). On the basis of the author's methodology, for a comprehensive assessment of the innovative development of the tourist sphere of the steppe regions of Russia, optimized indicators were selected to reflect the innovative development of the studied territories (the number of tour operators - developers of a new tourist product; the number of events aimed at the presentation of tourist resources; the number of special economic zones of the tourist and recreational type and the number of tourism clusters; the number of scientific publications on tourism, etc.). As a result of the analysis, unification and summation of the indicated indicators, a schematic map was drawn up, clearly reflecting the innovative development of the tourism sector of the steppe regions of Russia. Comparative geographical, statistical and geoinformation research methods allowed to comprehensively evaluate the innovative development of the tourism sphere of the steppe regions.

Results and discussion. In general, the innovative development of tourism in the steppe regions of Russia can be assessed as uniform, the difference in values between most regions is small. Nevertheless, the leading regions (Crimea, Sevastopol, Belgorod region) and outsiders (Volgograd, Saratov regions, a number of republics of the North Caucasus) are clearly distinguished.

Conclusions. To develop the tourism sphere and introduce innovations, first of all, it is necessary to create new special economic tourist-recreational clusters and zones, the number of which is insignificant in steppe regions; to create a system of scientific and personnel support of the tourism sphere in the region; to improve the taxation system for organizations involved in innovations in the tourism sphere.

Key words: innovative development, tourism, steppe regions.

Funding: The article is prepared within the framework of the state task «Problems of steppe nature management in the context of modern challenges: optimization of interaction between natural and socio-economic systems». The state registration number AAAAAA-A21-121011190016-1.

For citation: Chibilyova V.P., Filimonova I. Yu., Sviatokha N. Yu. Innovative Development of Tourism in the Steppe Regions of Russia. Vestnik Voronezskogo gosudarstvennogo universiteta. Seria: Geografia. Geoekologia, 2021, no. 4, pp. 3-12. (In Russ.) DOI: https://doi.org/10.17308/geo.2021.4/3744

\section{REFERENCES}

1. Grudinin D.A., Chibilev A.A. (ml.) Ob"ekty prirodnogo naslediya Orenburgsko-Kazakhstanskogo prigranich'ya i problemy ikh osvoeniya dlya tselei rekreatsii i turizma [Objects of natural heritage of the Orenburg-Kazakhstan border area and problems of their development for the purposes of recreation and tourism]. Byulleten' Orenburgskogo nauchnogo tsentra UrO RAN, elektronnyi zhurnal, 2012, no. 4, pp. 1-17. (In Russ.)

2. Kaizer F. Yu. Turistskii brend territorii kak sostavlyayushchaya formirovaniya turistskogo obraza Kemerovskoi oblasti (Kuzbassa) [The tourist brand of the territory as a component of the formation of the tourist image of the Kemerovo region (Kuzbass)]. Vestnik Voronezhskogo gosudarstvennogo universiteta. Seria: Geografia. Geoekologia, 2020, no. 1, pp. 67-76. DOI: https://doi.org/10.17308/ geo.2020.1/2663. (In Russ.)

3. Raskovalov V.P. Prirodnyi turistskii potentsial Permskogo kraya [Natural tourism potential of the Perm Region]. Vestnik Voronezhskogo gosudarstvennogo universiteta. Seria: Geografia. Geoekologia, 2020, no. 2, pp. 22-28. DOI: https://doi.org/10.17308/geo.2020.2/2881. (In Russ.)

4. Reiting innovatsionnogo razvitiya sub"ektov Rossiiskoi Federatsii [Rating of innovative development of the subjects of the Russian Federation], vyp. 6 / G. I. Abdrakhmanova, S. V. Artemov, P. D. Bakhtin i dr.; pod red. L. M. Gokhberga; Nats. issled. un-t «Vysshaya shkola ekonomiki». Moskow: NIU VShE, 2020. 264 p. (In Russ.)

Вестник ВГУ, Серия: География. Геоэкология, 2021, № 4, 3-12
5. Shvets Yu. Yu. Analiz faktorov innovatsionnogo razvitiya sfery turizma [Analysis of factors of innovative development of the tourism sector]. Uchenye zapiski Tavricheskogo natsional'nogo universiteta im. V.I. Vernadskogo. Seriya «Ekonomika i upravlenie», 2011, vol. 24 (63), no. 1, pp. 118-126. (In Russ.)

6. Sheremet E.N. Rol' ekologicheskogo turizma v razvitii munitsipal'nykh raionov Novosibirskoi oblasti [The role of ecological tourism in the development of municipal districts of the Novosibirsk region]. Vestnik Voronezhskogo gosudarstvennogo universiteta. Seria: Geografia. Geoekologia, 2018, no. 4, pp. 72-76. DOI: https://doi.org/10.17308/geo.2018.4/2270. (In Russ.)

7. Yakovlev I.G. Turistsko-rekreatsionnoe raionirovanie stepnykh regionov kak osnova vyyavleniya i obosnovaniya klyuchevykh elementov turistsko-rekreatsionnogo karkasa [Tourist and recreational zoning of steppe regions as a basis for identifying and justifying the key elements of the tourist and recreational framework]. Problemy regional'noi ekologii, 2017, no. 6, pp. 83-87. (In Russ.)

8. Hjalager A-M. 100 Innovations That Transformed Tourism. Journal of Travel Research, 2015, v. 54 (1), pp. 3-21. DOI: https://doi.or$\mathrm{g} / 10.1177 \% 2 \mathrm{~F} 0047287513516390$.

9. Pikkemaat B., Peters M., Bichler B.F. Innovation research in tourism: Research streams and actions for the future. Journal of Hospitality and Tourism Management, 2019, v. 41, pp. 184-96. DOI: https://doi.org/10.1016/j. jhtm.2019.10.007.
.

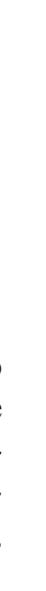

\author{
.
}


Conflict of interests: The authors declare no information of obvious and potential conflicts of interest related to the publication of this article.

Received: 11.05.2021

Accepted: 23.11.2021

\section{Чибилёва Валентина Петровна}

кандидат географических наук, научный сотрудник Института степи Уральского отделения Российской академии наук - обособленного структурного подразделения Федерального государственного бюджетного учреждения науки Оренбургский федеральный исследовательский центр Уральского отделения Российской академии наук, г. Оренбург, Российская Федерация, ORCID: 0000-0002-9428-1864, e-mail: tina-chibilyova@, mail.ru

Филимонова Ирина Юрьевна

кандидат географических наук, доцент, старший научный сотрудник Института степи Уральского отделения Российской академии наук - обособленного структурного подразделения Федерального государственного бюджетного учреждения науки Оренбургский федеральный исследовательский центр Уральского отделения Российской академии наук, г. Оренбург, Российская Федерация, ORCID: 0000-0002-9773-2173, e-mail: filimo-irina@yandex.ru

Святоха Наталья Юрьевна

кандидат географических наук, научный сотрудник Института степи Уральского отделения Российской академии наук - обособленного структурного подразделения Федерального государственного бюджетного учреждения науки Оренбургский федеральный исследовательский центр Уральского отделения Российской академии наук, г. Оренбург, Российская Федерация, ORCID: 00000002-5707-2932, e-mail: osugeo@yandex.ru

\section{Valentina P. Chibilyova}

Cand. Sci. (Geogr.), Researcher of the Steppe Institute of the Ural Branch of the Russian Academy of Sciences a separate structural unit of the Federal State Budgetary Institution of Science Orenburg Federal Research Center of the Ural Branch of the Russian Academy of Sciences, Orenburg, Russian Federation, ORCID: 0000-0002-94281864, e-mail: tina-chibilyova@mail.ru

Irina Yu. Filimonova

Cand. Sci. (Geogr.), Associate Professor, Senior Researcher of the Steppe Institute of the Ural branch of the Russian Academy of Sciences - a separate structural division of the Federal state budgetary institution of science Orenburg Federal research center of the Ural branch of the Russian Academy of Sciences, Orenburg, Russian Federation, ORCID: 0000-0002-9773-2173, e-mail: filimo-irina@yandex.ru

Natalia Yu. Sviatokha

Cand. Sci. (Geogr.), Researcher of the Steppe Institute of the Ural Branch of the Russian Academy of Sciences a separate structural unit of the Federal State Budgetary Institution of Science Orenburg Federal Research Center of the Ural Branch of the Russian Academy of Sciences, Orenburg, Russian Federation, ORCID: 0000-0002-57072932, e-mail: osugeo@yandex.ru 